\title{
The Terrible Bite of Fire: Metre, Sound Change, and Emendation in Beowulf 1122
}

\section{Nelson Goering}

To cite this article: Nelson Goering (2020): The Terrible Bite of Fire: Metre, Sound Change, and Emendation in Beowulf 1122, English Studies

To link to this article: https://doi.org/10.1080/0013838X.2020.1847918

册 Published online: 16 Dec 2020.

Submit your article to this journal $₫$

Q View related articles $\widetilde{ }$

View Crossmark data $₫$ 


\title{
The Terrible Bite of Fire: Metre, Sound Change, and Emendation in Beowulf 1122
}

\author{
Nelson Goering \\ Somerville College, University of Oxford, Oxford, UK
}

\begin{abstract}
Line 1122 of Beowulf represents a problem where the findings of metrics, historical phonology, and the reading of the manuscript are in conflict with one another. I revive and adapt Tolkien's proposal to emend läðbite lìces lìg ealle forswealg to läðbite lïges lic eall forswealg "the cruel bite of fire swallowed up the entire bodies". This emended reading allows the line to be scanned in accordance with Kaluza's law without any complications to the standard historical phonology of Old English, and furthermore improves both the syntax and semantics of the overall passage.
\end{abstract}

\section{ARTICLE HISTORY}

Received 5 September 2020 Accepted 16 October 2020

\section{KEYWORDS}

Metrics; phonology; Kaluza's law; Beowulf; emendation

The process of turning marks on parchment into meaningful poetry can often be an elaborate project, with palaeographic, linguistic, and metrical considerations all playing their part in establishing the text. Sometimes medieval ink-scratches may prove to be fairly easily read and interpreted; in other cases, tensions arise: a linguistically grounded interpretation creates a metrical difficulty, or the physical ink shapes are at odds with what other factors suggest.

Line 1122 of Beowulf - which describes the burning of bodies on a funeral pyre in the Finnesburg episode - is one of these difficult cases. Among other issues, a tension between metrical and linguistic considerations has previously led to the proposal of a new sound change in the history of Old English. I will begin by trying to lay out the nature of this problem as clearly as possible, reviewing the scansion of 1122a and the operation of Kaluza's law, as well as some of the basic sound changes that affected word-final vowels in prehistoric Old English. My argument is that it is neither the metrics nor the historical phonology which should give or be adjusted; rather, all the issues involved in 1122 stem from a rather minor slip by a copyist at some point during the transmission of the text of Beowulf. To address this issue, I revive and adjust an emendation proposed by Tolkien which avoids the various metrical, historical-phonological, syntactic, and semantic problems created by non-emending readings.

\section{1122a: Text and Scansion}

Line 1122 occurs in the Finnesburg episode of Beowulf (roughly lines 1071-1159, though the exact starting point is slightly fuzzy). In the aftermath of a battle, a pyre is made for an 
uncle and nephew who died in the fighting. The process is described in some detail, and the burning of the bodies themselves is recounted as follows in lines 1120-1124. I give the text as conventionally understood and punctuated, following Klaeber Four, with a translation of the standard interpretation by Fulk: ${ }^{1}$

Hafelan multon,

bengeato burston ðonne blōd ætspranc,

1122 lāobite līces; līg ealle forswealg, gǣsta gīfrost, pāra ðe pǣr gūð fornam

1124 bèga folces.

"Heads melted, wound-openings broke asunder when blood burst out, hostile bites in the body. The flame, most ravenous of spirits, swallowed all of those of both nations whom war had carried off there."

There are no particular difficulties in reading the letter-forms of the manuscript (see Figure 1 and, for the now-damaged letters, Figure 2), though the details of capitalisation and punctuation are, as usual, supplied by the editors in line with their understanding of the passage's syntax and meaning.

The starting point for reconsidering this passage is a potential metrical issue in verse $1122 \mathrm{a}$, lāðbite lìces. Under the mainstream Sieversian framework for understanding Old English metrics, ${ }^{2}$ this is clearly a variety of type A2a, $\leq \perp \leq \times .^{3}$ Two main lifts are filled by alliterating $l \bar{a} \partial$ - and $l \bar{l}$-, and - $\dot{c} e s$ forms a final unstressed dip or drop. The metrical issue concerns the second metrical position, which is filled by two syllables in resolution. That is to say, -bite (which carries secondary stress, being the second element of a compound) counts as the metrical equivalent of a monosyllable. This may be compared with an equivalent verse without resolution, with the four metrical positions separated by spaces and numbered:

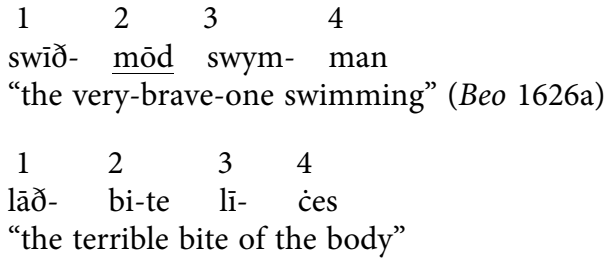

These have precisely the same metrical structure, ecxept that -mōd is monosyllabic while -bite is a resolved equivalent.

\footnotetext{
${ }^{1}$ Fulk, Bjork and Niles, Klaeber's Beowulf ; Fulk, The Beowulf Manuscript, 159-61. Every recent edition and translation of the poem I have been able to check has been in accord with this in all relevant essentials.

${ }^{2}$ Terasawa, Introduction. The foundational works for this framework are Sievers, "Rhythmik I"; Sievers, "Rhythmik II"; Sievers, "Rhythmik III"; Sievers, Altgermanische Metrik, which has more recently been built on by many others: Cable, Meter and Meolody; Cable, The English Alliterative Tradition; Suzuki, Metrical Organization; Yakovlev, "Development of Alliterative Metre." The core of Sievers' findings also form the foundation for alternative frameworks, especially the word-foot theory of Russom, Old English Meter; Russom, Evolution of Verse Structure. The divergences between these metrical theories make no material difference to the problem at hand. I assume the Sieversian notation will be more familiar to most, and so adopt this framework in the main text, but I also supply word-foot notations in footnotes. ${ }^{3}$ In Russom's word-foot notation, this would be Ss/Sx, or indicating resolution Ssw/Sx. Stockwell, "Recent Theories."
} 


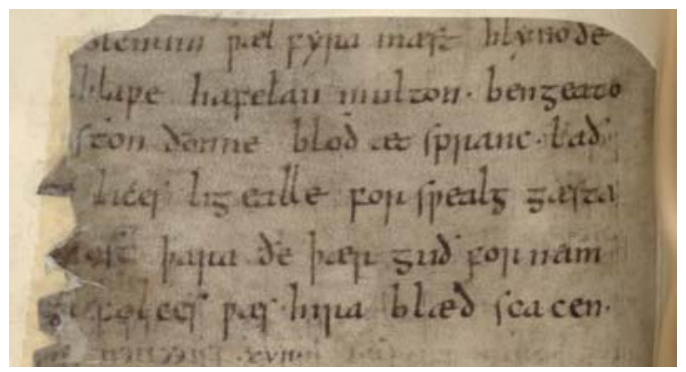

Figure 1. MS Cotton Vitellius A xv, 154v (BL 157v), reproduced with permission of the British Library. $\odot$ British Library Board (Cotton Vitellius A xv, 157v).

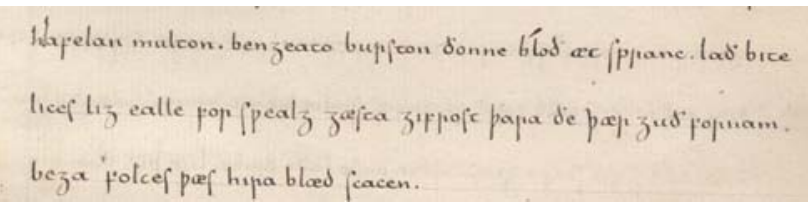

Figure 2. Thorkelín Transcript A, from Electronic Beowulf 4.0 (Kiernan, Electronic Beowulf), used with permission of Kevin Kiernan.

Resolution is itself not problematic, and is a standard part of mainstream metrical theories for Old English. ${ }^{4}$ The issue with 1122a instead involves a specific set of restrictions on resolution known collectively as Kaluza's law.

\subsection{Kaluza's Law}

Kaluza's law is a substantial topic, too much so to go over in full here. ${ }^{5}$ What is relevant here is that the two syllables -bi-te fall in what may be called a Kaluza position, that is, the position immediately after a heavy syllable. Within a Kaluza position, two syllables resolve together into a single metrical position if and only if they are both light syllables.

A heavy syllable is any that contains a long vowel (or long diphthong) or which ends in a consonant. A light syllable is one that ends in a short vowel. In 1122a, lāð- is clearly a heavy syllable (it both has a long vowel and ends in a consonant), and so conditions a "Kaluza position" immediately after it. I will write this conditioning syllable in italics below. The two syllables after this, in the "Kaluza position", are in bold:

lāð-bi-te līces

"the terrible bite of the body" (Beo 1122a)

By Kaluza's law, we would expect both bolded syllables, being in "Kaluza position", to be light (since our scansion demands that they resolve). The syllable $b i$-certainly ends in a short vowel, and so is unambiguously light. The weight of the syllable -te is, then, the key question: is this light or heavy?

${ }^{4}$ Sievers, "Rhythmik I," 217-8; Suzuki, "Defense of Resolution"; Russom, "Bard's-Eye View."

${ }^{5}$ For further details and data see: Bliss, The Metre of Beowulf , 27-35; Fulk, History, 153-68; Suzuki, "Kaluza's Law Reconsidered"; Goering, "Linguistic Elements," 73-155. 
The answer is not self-evident, since Kaluza's law depends not on the lengths of vowels of the Late Old English of the scribes, but of the Early Old English of some three centuries prior. Final $-e$ in the Beowulf manuscript can potentially reflect any of three vowels in Early Old English: either short ${ }^{*}-i$ or long ${ }^{*}-\bar{i}$ or $^{*}-\bar{e} .^{6}$ Short ${ }^{*}-t i$ would be a light syllable, but either ${ }^{*}-t \bar{\imath}$ or ${ }^{*}-t \bar{e}$ would be heavy syllables. To find out whether $1122 \mathrm{a}$ adheres to Kaluza's law or not, with the needed two light syllables in -bite, we need to take a closer look at this word's grammatical form in Early Old English.

\section{The Problem}

The traditional understanding of $1122 \mathrm{a}$, as outlined above, takes -bite as a nominative plural: the "bites" are in apposition to bengeato, the "wound-openings" as the subject of the plural verb burston. Etymologically, bite belongs to the nominal class known as $i$-stems, which historically had a distinction of length between the nominative singular and plural: a short vowel ending in the singular, ${ }^{\star} b i t i$, and a long ending in the plural, * biti (see below for further discussion).

The basic problem with $1122 \mathrm{a}$, then, is a mismatch between the traditional grammatical understanding of bite as an $i$-stem nominative plural - Early Old English ${ }^{\star} b i t \bar{i}$, with a final long vowel - and the expectation from Kaluza's law that these two resolved syllables should both be light. That is, grammar (under the traditional view) suggests ${ }^{\star} b i t \bar{i}$, while metrics suggests ${ }^{\star} b i t i$ (with a short final vowel).

There are several possible solutions to this mismatch. One would be to accept 1122a as metrically deficient. This is not a very comfortable solution, since Kaluza's law is remarkably regular in A2a verses, with an accuracy of over $97 \%{ }^{7}$ While not impossible, the odds are decidedly against this being the correct choice.

A second possibility is to reconsider the historical phonology, proposing a new sound change so that plural ${ }^{\star} b i t \bar{i}$ becomes ${ }^{\star} b i t i$ through an extra process of vowel shortening. This is argued explictly by Fulk, ${ }^{8}$ and seems implict in Bliss. ${ }^{9}$ This would allow the plural reading to be kept and reconciled with the metre, but I will argue shortly against this approach.

A third option is to reconsider the reading of the passage so as to interpret bite not as a nominative plural, but as some other form that would be expected to have the short ending ${ }^{\star} b i t i$. This is the solution I will argue for below.

\section{Sound Changes}

Early Germanic had a wide variety of word-final vowels, which were reduced fairly dramatically during the prehistory of what would become Old English. ${ }^{10}$ By the Early Old

\footnotetext{
${ }^{6}$ Or potentially short*-æ, if this existed (which I doubt); for discussion, see Goering, "Linguistic Elements," 98-105. The (non)existence of short ${ }^{*}$-æ is fortunately not relevant to the question at hand, which likely concerns an $i$-quality vowel, whether long or short.

${ }^{7}$ Fulk, History, 159-65; Goering, "Linguistic Elements," 126-7, 129.

${ }^{8}$ Fulk, History, Appendix C.3, 421.

${ }^{9}$ Bliss, The Metre of Beowulf , 119.

${ }^{10}$ For overviews, from different perspectives, see in particular Hollifield, "Final Syllables"; Stiles, "Final Syllables"; Boutkan, The Germanic 'Auslautgesetze'.
} 
English period, there were five final vowels: the three long vowels ${ }^{\star}-\bar{\imath},-\bar{e}$, and $-\bar{a}$, and the two short vowels $-i$ and $-u .^{11}$

There are three major sound changes that helped create the Early Old English system which are relevant to the issue at hand: (1) an early shortening of certain final vowels; (2) the loss of final ${ }^{*}-z$, which made new vowels final; and (3) the process conventionally known as high-vowel deletion.

The first of these was the change of final ${ }^{\star}-\bar{\imath}$ and ${ }^{\star}-\bar{u}$ to become ${ }^{\star}-i$ and ${ }^{\star}-u{ }^{12}$ This shortening only took place when the vowel was absolutely final: a word like ${ }^{\star} b a n d \bar{\imath}$ "bond" became *bandi, but words like *alßīz "elves" or ^bitì $z$ "bites" were unaffected, with the ${ }^{*}-z$ "protecting" the vowels from shortening.

Sometime after this change, however, this ${ }^{*} z$ was itself lost. This meant that there were now once again word-final ${ }^{\star}-\vec{\imath}$ s in the language, as ${ }^{\star} a l \beta \bar{\imath} z$ and ${ }^{\star} b i t \bar{i} z$ became ${ }^{\star} a l \beta \bar{\imath}$ and ${ }^{\star} b i t \bar{i}$. Among $i$-stem nouns such as "elf" and "bite", this created contrasts where the nominative singular and nominative plural were distinguished by final vowel length alone: singulars ${ }^{\star} a l \beta i$, ${ }^{\star} b i t i$, plurals ${ }^{\star} a l \beta \bar{\imath},{ }^{\star} b i t \bar{i}$.

The final change, in very late prehistory (after changes such as umlaut), is the loss of short high vowels - that is, ${ }^{\star} i$ and ${ }^{\star} u$ - in some contexts. Putting it a little over-simply, final ${ }^{*}-i$ was retained immediately after a light syllable, but lost immediately after a heavy syllable. ${ }^{13}$ Thus a word like *meri "sea" (from Proto-Germanic *mari) or nominative singular ${ }^{\star} b i t i$ "bite" both retained their final short ${ }^{\star}-i$ 's. On the other hand, words like ${ }^{\star} b$ oend $i$ "bond" (from *bandi by early shortening of final ${ }^{*}-\bar{\imath}$ ) or nominative singular ${ }^{*}$ el $\beta i$ (from ${ }^{\star}$ al $\beta i z$ by $z$-loss) both lost their short final ${ }^{*}-i$ 's, since they immediately followed the heavy syllables ${ }^{*}$ boen- and ${ }^{*}$ al- (both heavy because they ended in consonants).

Importantly, final ${ }^{*}-\bar{\imath}$ was not affected by this loss at all. The nominative plural ${ }^{\star} e l \beta \bar{\imath}$ retained its final vowel, even though the preceding syllable was heavy. The contrast of singular ${ }^{*} e l \beta i$ becoming elf, but plural ${ }^{*} e l \beta \bar{\imath}$ not losing its vowel, is an important linguistic indicator that short ${ }^{\star}-i$ versus long ${ }^{\star}-\bar{i}$ was still a contrast made in Old English in the late prehistoric period. High vowel deletion likely took place in the early seventh century, ${ }^{14}$ ensuring that final long vowels (specifically ${ }^{\star}-\bar{\imath}$ ) were present in the language at the cusp of the historical period. If the dating to approximately 600 is even remotely correct (and it should be noted that absolute datings of prehistoric sound changes are notoriously difficult), then it would seem that Cædmon's parents or grandparents must still have had them, and it is not implausible that he and his contemporaries still did.

These three phonological developments can be summarised as a table, with the Late West Saxon (LWS) forms familiar from most manucripts given at the end. ${ }^{15}$ These show the typical later Old English merger of $-i,-\bar{i}$, and $-\bar{e}$ all as $-e$.

\footnotetext{
${ }^{11}$ On the question of a possible sixth vowel, see note 6 above.

${ }^{12}$ Ringe and Taylor, Development of Old English, 15-6.

${ }^{13}$ For a more precise discussion, see Goering, "Foot Structure."

${ }^{14}$ Luick, Historische Grammatik, 287; Ringe and Taylor, Development of Old English, 292.

${ }^{15}$ Note that the sound changes generally give Anglian forms, while the final row is not just later, but also in West Saxon. I do not mean to imply that ylfe is a direct descendant of Anglian *elßì.
} 


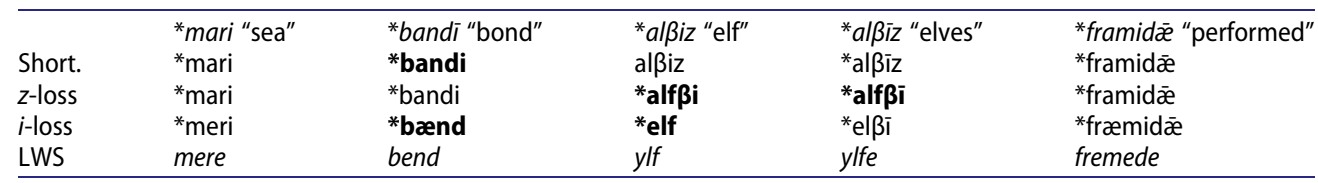

It is clear that by these standard sound changes, the dilemma facing the traditional reading of $1122 \mathrm{a}$ is real: the final vowels of ${ }^{\star} b i t \bar{i}$ and ${ }^{\star} a l \beta \bar{\imath}$ must have remained long through the period of high vowel deletion, which was only perhaps a century before the likely date of composition of Beowulf (perhaps very roughly around 700). ${ }^{16}$ To judge by Kaluza's law, according to which historical ${ }^{\star}-\bar{a}$ and ${ }^{\star}-\bar{e}$ routinely count as long vowels in Beowulf, there was no general shortening of final vowels during this period. All other things being equal, we would expect final ${ }^{\star}-\bar{\imath}$ to still be a long vowel in Beowulf.

There are, however, relatively few examples of final ${ }^{\star}-\bar{\imath}$ in what have traditionally been regarded as the core contexts for Kaluza's law. To allow the vowel to scan short in this lone verse, Fulk ${ }^{17}$ proposes a special round of $\bar{i}$-shortening between the operation of high vowel deletion and the composition of Beowulf. By this, we would have the development of ${ }^{\star} b i t \bar{i} z$ to ${ }^{\star} b i t \bar{i}$ by $z$-loss, and then further to ${ }^{\star} b i t i$ by $i$-shortening (even as ${ }^{\star}-\bar{e}$ and ${ }^{\star}-\bar{a}$ remained long).

A parallel shortening of this sort clearly took place in Old High German, where a plural like gasti escapes the German form of high vowel deletion, but the vowel is never marked as long - and in Old High German, unlike Old English, we possess manuscripts where such marking might be expected. ${ }^{18}$ This is an interesting parallel, but is an argument of plausibility only, not direct evidence. Many details of vowel reductions are different in Old High German and Old English, both in the details of what happens, and the chronology in which it takes place.

What grounds are there for assuming that a similar change happened in Old English? Aside from Beowulf 1122a itself, where a nominative plural ${ }^{\star} b i t i$ would be metrically convenient, there is to my knowledge no further evidence of any sort for this extra round of $i$-shortening. This sound change is posited, in effect, to account for this single verse in Beowulf. ${ }^{19}$ This is a very slender basis on which to posit a sound change, however plausible, and all the more so because $1122 \mathrm{a}$ reveals, on closer inspection, other problems which cast doubt on the reliability of the traditional reading of this half-line.

\footnotetext{
${ }^{16}$ Beowulf cannot be dated precisely, and disagreement remains about the exact chronological bounds for the poem's composition. For reviews of the chief literature and arguments in favour of a date between perhaps 650 and 750 , see Fulk, "Beowulf and Language History"; Neidorf, "Introduction."

${ }^{17}$ Fulk, History, Appendix C.3, 421.

${ }^{18}$ For further details, see Braune, Althochdeutsche Grammatik, 201 (§215, n. 4).

${ }^{19}$ It may be worth noting in passing that there is more metrical evidence available as well. Six type-C verses ending in compounds or names, such as 116a hü hit Hringdene "how the Ring-Danes (lived in) it", show etymological *-ī, in every case failing to resolve. This failure of resolution suggests the ending was heavy, with a long vowel. Such verses are of less value, since even short endings may fail to resolve in verse-final compounds, but the type still adheres to Kaluza's law around $90 \%$ of the time. For six verses (116b, 1279b, 1996a, 2363a, 2479a, 2916a) with the same ending to all fail to resolve adds some weight to the idea that this ending did in fact contain a long vowel, which further weakens the argument for a short-vowel version of this plural ending in 1122a. For details, see Goering, "Linguistic Elements," $120-3$.
} 


\section{1122a Reconsidered}

While editors and translators have been able to wring sense from $1122 \mathrm{a}$ as it stands, the traditional construals involve difficulties both concerning the syntax of the larger passage, and the semantics of bite. Combined with the linguistic-metrical difficulties already discussed, it may be more promising to suggest that this constellation of problems has arisen because of an error in the transmission of the text.

As noted above, the traditional reading understands lāðbite to be in apposition to bengeato "wound-openings", and so to be the subject of burston in line 1121a. This is a possible reading, but syntactically awkward: the subordinate clause donne blod oxtspranc (1121b), with its own subject and (singular) finite verb, intervenes between bengeato and läðbite.

Semantically, the traditional gloss of läðbite is "hostile bite, wound". This takes bite as a concrete noun, the physical result of "biting" or wounding, a lasting injury to the body. More typically, however, $i$-stem nouns are abstract or action nouns. ${ }^{20}$ We would accordingly expect this to mean the action of "biting": as in the "bite of the wind" (action noun) rather than "a snake bite" (concrete noun).

This is reinforced by the two other occurrences of bite in Beowulf, which are both action nouns: ${ }^{21}$

æfter billes bite

"after the biting of the sword" (Beo 2060a)

bite īrena

"(the armour experienced) the biting of iron (swords)" (Beo 2259b)

Most of the instances of bite in Old English are, to judge by the Dictionary of Old English and its Corpus, action nouns of this type. The main exceptions are when bite occurs as a translation of Latin morsus, where loan-translation effects may be a factor, and a couple of instances referring to insectoid bites or stings: ${ }^{22}$

wið scorpiones bite and nǣdran slite

“against scorpion's bite and snake’s rent” (Medicina de Quadrupedibus 4.15)

This picture also generally holds into Early Middle English, where the following uses of bite are typical: ${ }^{23}$

i pan compe pēr uēollen ten pūsend cnihten

purh stēles biten

"in that battle there fell ten thousand knights through the biting of steel"

(Brut 14953-14954)

hēr ich abīde pe bite of sweordes egge

\footnotetext{
${ }^{20}$ Krahe and Meid, Wortbildungslehre, 65-7; Tolkien, Finn and Hengest, 113.

${ }^{21}$ Williams, Finn Episode, 77.

${ }^{22}$ Cited, with adjustment, from Cockayne, Leechdoms, 346.

${ }^{23}$ Cited, with adjustment, respectively from Madden, Brut, III. 202, and from d'Ardenne and Dobson, Seinte Katerine, 126. The lineation for Brut is after Brook and Leslie, Lazamon: Brut, 782.
} 
"I here await the bite of sword's edge" (Seinte Katerine 880)

A concrete sense of bite cannot be definitively ruled out, but it is certainly the less typical choice compared with construing bite as an action noun. Metrically, the verse was already suspicious for either not scanning or forcing the assumption of an extra sound change; to this may be added the syntactic awkwardness of the intervening subordinate clause and the unusual semantics the traditional reading assumes for bite. $1122 \mathrm{a}$ is, then, suspicious from any angle we look at it.

\section{1122a: Emendation?}

Tolkien, on the strength only of syntactic and semantic considerations (metre plays no role in his argument), proposes an emendation to solve the various difficulties affecting this line. ${ }^{24}$ He suggests $l i c$ and lig have been flipped in transmission, ${ }^{25}$ so that we should emend to:

1120

Hafelan multon,

bengeato burston ðonne blōd ætspranc.

1122 Lāðbite lī $\dot{g}$ es lī $\dot{c}$ eallẹ forswealg,

gǣsta gīfrost, pāra ðe pǣr gūð fornam

1124 bēga folces.

The construal of the passage is still open to different interpretations, but I would propose that the simplest translation (already reflected in my punctuation above) is: ${ }^{26}$

Heads melted, gaping wounds burst when blood sprang out. The cruel bite of fire, greediest of spirits, swallowed up the entire bodies of those whom battle had there taken away of the host of both.

\footnotetext{
${ }^{24}$ Tolkien, Finn and Hengest, 113.

${ }^{25}$ Certain editors and textual critics have broken down mechanical errors in copying into a particular typology; see Orton, Transmission for an extensive overview. Under such a typology, the proposed error would be a type of transposition (or metathesis), flipping two words, or two letters in similar contexts. I do not know of a perfectly precise parallel for two such similar words being transposed within a line, but a few examples of ordinary metathesis (all of adjacent words) may be seen in Orton, Transmission, 120-3; Orchard, Critical Companion, 44, n. 138. Confusion based on two similarlooking words is also the driving factor behind eye-skip: Orton, Transmission, 32-6; Orchard, Critical Companion, 44, n. 136. More important than trying to fit this into a taxonomy of scribal changes is the nature of late Old English copying, focused primarily on the shapes of words; for a general overview, see Neidorf, The Transmission ofBeowulf. The absence of a larger number of comparable errors of this sort may simply a function of the relatively small corpus provided by Beowulf, or even the whole Old English poetic corpus: opportunities for such cross-word transposition would not be all that frequent, compared to most other kinds of error, and we would expect a scribe to make an error only in a minority of possible cases.

${ }^{26}$ Tolkien's own understanding of the passage is rather different. According to Tolkien's son and editor, he rather hastily altered his own preexisting translation to reflect this emendation, arriving first at "their gaping wounds burst open, and the blood sprang away from the cruel devouring of the flame. Flame swallowed up them all ... "; Tolkien, Beowulf, 117. A more polished translation (clearly developed from this subsequently) was published, also posthumously, in Tolkien, Finn and Hengest, 153: "Heads crumbled, gaping wounds burst open, when the blood sprang away from the cruel bite of flame. That greediest of spirits consumed all the flesh of those whom in that place war had carried off of both parties of the people". As far as I know, Tolkien never explained his view of the syntax here in detail, but he seems to take läðbite as a dative, in keeping with the gloss by Sedgefield, Beowulf , 205 and the interpretation of Williams, Finn Episode, 77-8, who translated the unemended passage as 'then the blood sprang forth with the biting of the body (by the flames)'. Tolkien appears to take the sense as more ablative than instrumental, but neither reading seems very plausible. Despite following his emendation, my overall construal differs considerably from Tolkien's, taking $1122 \mathrm{a}$ not as the end of the first sentence, but as the start of the second.
} 
This solves all of the issues identified above. Under this reading, lāðbite lìges would mean "the hostile biting of fire", with bite as a singular action noun. The half-line begins a new sentence, the immediate subject offorswealg, so the difficulties of apposition disappear. And as a nominative singular $i$-stem noun, bite would reflect Early Old English ${ }^{\star} b i t i$ with no sound changes except those already identified on linguistic grounds: Proto-Germanic ${ }^{\star} b i t i z$ would become ${ }^{\star} b i t i$ simply by $z$-loss. The two short syllables in ${ }^{\star} b i$ - $t$, both ending in short vowels, consequently resolve as called for by Kaluza's law. ${ }^{27}$

One potential drawback to this emendation is that it requires the further change of manuscript ealle to eall, making $1122 \mathrm{~b}$ comparable to $2080 \mathrm{~b}$ :

lìc eall forswealg

"(Grendel) swallowed all the body" (Beo 2080b)

If eall is an adjective in $1122 \mathrm{~b}$, it would, under the emended reading, modify $l i \vec{c}$, an accusative plural noun, and so should be in the endingless strong neuter accusative plural. If, instead, eall was originally intended as an adverb, which is entirely plausible for the emended passage, the form should still be endingless. ${ }^{28}$ Either way, this supposes a two-stage process of transmission: first there was the initial error of transposition (palaeographically highly plausible), and later a correction of what by then appeared to be an inadvertent omission of a masculine accusative plural grammatical ending. ${ }^{29}$

\section{Choosing an Explanation}

Fundamentally, each person who engages with the textual criticism of Beowulf will have to choose for themself which approach they find most convincing depending on their editorial philosophy. No absolute certainty is possible, and there are costs to any approach. If we accept the manuscript reading, we must accept that this passage involves unlikely features of syntax and semantics. We must further either posit an extra, otherwise unsupported (though not implausible) sound change in the history of Old English, or else tolerate $1122 \mathrm{a}$ as a violation of Kaluza's law.

As should be clear, I prefer to see emendation as the least costly alternative. Kaluza's law is not exceptionless, but is demonstrably very robust. I am also very reluctant to posit a sound change on the basis of a single half-line, without some further supporting evidence. The congruence of a metrical anomaly with issues of both syntax and semantics is a classic sign of a transmission error in the text of Beowulf. ${ }^{30}$ The emendation of 1122 to läðbite lìges lïc eall forswealg does carry the cost of "meddling" with the manuscript. This cost is, however, mitigated by the palaeographic ease of explaining the error and the uncontested presence of many other scribal errors in the manuscript. The resulting emended line avoids all the issues of metrics, historical phonology, syntactic construal,

\footnotetext{
${ }^{27}$ The formulaic association of läð and lïg at $83 a$ and 2305 may also reinforce the proposed reading of $1122 a$; my thanks to Francis Leneghan for pointing out these parallels.

${ }^{28}$ Cameron, Amos and Healey, Dictionary of Old English, s.v. eall adv.

${ }^{29}$ Examples of other proposed two-stage errors include Tolkien's compelling account of line 306 (Tolkien, Beowulf, 201-4), the sequence implied by emending 1382 a from wundini to wundnan (Fulk, Bjork and Niles, Klaeber's Beowulf , 202; Neidorf, "The Archetype of Beowulf," 234), and the addition of the majuscule $H$ - to the name Hunferð (Gerritsen, "The Beowulf Manuscript," 20). For further discussion and references, see Lapidge, "The Archetype of Beowulf," 36.

${ }^{30}$ See especially Fulk, "Textual Criticism," 39. Also compare Fulk, "Textual Criticism of Klaeber's Beowulf," 151 (cf. 143-4); Neidorf, The Transmission of Beowulf, 19.
} 
and the unusual semantics of bite which trouble an unemended reading. All this, I suggest, supports the idea that the Beowulf poet composed not about "terrible bites of the body", but rather the "terrible bite of fire" which consumed the corpses on the funeral pyre.

\section{Acknowledgements}

I first presented this material at the Anglo-Saxon Metre and Literary Studies workshop in Oxford on 30 October 2019, and I would like to thank all the participants for their helpful comments and feedback. I am further grateful to Patrick Stiles for his many useful corrections and improvements on a draft of this article. This research was funded in part by the British Academy project Norse Influence on Middle English Prosody.

\section{Disclosure Statement}

No potential conflict of interest was reported by the author(s).

\section{Funding}

This work was supported by British Academy [grant number pf170159].

\section{ORCID}

Nelson Goering (D) http://orcid.org/0000-0003-2565-3369

\section{References}

Bliss, Alan J. The Metre of Beowulf. Oxford: Blackwell, 1962.

Boutkan, Dirk. The Germanic 'Auslautgesetze'. Amsterdam: Rodopi, 1995.

Braune, Wilhelm. Althochdeutsche Grammatik I: Laut- und Formenlehre. 15th ed. Edited by Ingo Reiffenstein. Tübingen: Max Niemeyer Verlag, 2004.

Brook, G. L., and R. F. Leslie, eds. Lazamon: Brut. Vol. 2. The Early English Text Society No. 277. Oxford: Oxford University Press, 1978.

Cable, Thomas M. The Meter and Melody of Beowulf. Urbana: University of Illinois Press, 1974.

— The English Alliterative Tradition. Philadelphia: University of Pennsylvania Press, 1991.

Cameron, Angus, Ashley Crandell Amos and Antonette diPaolo Healey, eds. Dictionary of Old English: A to I Online. Toronto: Dictionary of Old English Project, 2018.

Cockayne, Oswald. Leechdoms, Wortcunning, and Starcraft of Early England. Vol. I. London: Longman, Green, Longman, Roberts, \& Green, 1864.

d'Ardenne, S.R.T.O., and E. J. Dobson, eds. Seinte Katerine: Re-Edited from MS Bodley 34 and the Other Manuscripts. The Early English Text Society S.S. 7. Oxford: Oxford University Press, 1981.

Fulk, R. D. A History of Old English Meter. Philadelphia: University of Pennsylvania Press, 1992. "Textual Criticism". In A Beowulf Handbook, edited by Robert E. Bjork and John D. Niles, 35-53. Exeter: University of Exeter Press, 1997.

"The Textual Criticism of Frederick Klaeber's Beowulf." Edited by Andrew Wawn, Graham Johnson and John Walter, 131-153. Turnhourt: Brepols, 2007.

— University Press, 2010.

_ "Beowulf and Language History." In Neidorf, The Dating of Beowulf, 19-36. 
Fulk, R. D., Robert E. Bjork and John D. Niles, eds. Klaeber's Beowulf and the Fight at Finnsburg. 4th ed. Corrected reprint. Toronto: University of Toronto Press, 2009.

Gerritsen, Johan. "Have with you to Lexington! The Beowulf Manuscript and Beowulf." In In Other Words, edited by J. Lachlan Mackenzie and Richard Todd, 15-34. Berlin: De Gruyter Mouton, 1989.

Goering, Nelson. "Early Old English Foot Structure”. Transactions of the Philological Society 114, no. 2 (2016): 171-197.

"The Linguistic Elements of Old Germanic Metre: Phonology, metrical theory, and the development of alliterative verse". DPhil diss., University of Oxford, 2016.

Hollifield, Patrick Henry. "The Phonological Development of Final Syllables in Germanic". Die Sprache 26 (1980): 19-53, 145-178.

Kiernan, Kevin S., ed. Electronic Beowulf, 2015. https://ebeowulf.uky.edu/ebeo4.0/CD/main.html

Krahe, Hans, and Wolfgang Meid. Germanische Sprachwissenschaft III: Wortbildungslehre. Berlin: Walter de Gruyter, 1967.

Lapidge, Michael. "The Archetype of Beowulf." Anglo-Saxon England 29 (2000): 5-41.

Luick, Karl. Historische Grammatik der englischen Sprache. Leipzig: Chr. Herm. Tauchnitz, 1921.

Madden, Frederic, ed. Lazamon's Brut, or Chronicle of Britain. London: Society of the Antiquaries of London, 1847.

Neidorf, Leonard. "Introduction". In Neidorf, The Dating of Beowulf, 1-18.

Neidorf, Leonard, ed. The Dating of Beowulf: A Reassessment. Cambridge: D.S. Brewer, 2014.

Neidorf, Leonard. The Transmission of Beowulf. Ithaca: Cornell University Press, 2017.

"The Archetype of Beowulf." English Studies 99, no. 3 (2018): 229-242.

Orchard, Andy. A Critical Companion to Beowulf. Cambridge: D. S. Brewer, 2003.

Orton, Peter. The Transmission of Old English Poetry. Turnhout: Brepols, 2000.

Ringe, Don, and Ann Taylor. The Development of Old English. A Linguistic History of English, vol. 2. Oxford: Oxford University Press, 2014.

Russom, Geoffrey. Old English Meter and Linguistic Theory. Cambridge: Cambridge University Press, 1987.

"A Bard's-Eye View of the Germanic Syllable." The Journal of English and Germanic Philology 101, no. 3 (2002): 305-328.

The Evolution of Verse Structure in Old and Middle English Poetry. Cambridge: Cambridge University Press, 2017.

Sedgefield, Walter John, ed. Beowulf. 2nd ed. Manchester: University Press, 1913.

Sievers, Eduard. "Zur rhythmik des germanischen alliterationverses. I." Beiträge zur Geschichte der deutschen Sprache und Literatur 10 (1885): 209-314.

— "Zur rhythmik des germanischen alliterationverses. II.” Beiträge zur Geschichte der deutschen Sprache und Literatur 10 (1885): 451-545.

— "Zur rhythmik des germanischen alliterationverses. III." Beiträge zur Geschichte der deutschen Sprache und Literatur 12 (1887): 454-482.

Altgermanische Metrik. Halle: Max Niemeyer, 1893.

Stiles, Patrick V. "The Gothic Nominative Singular Brōpar 'Brother' and the Reflexes of IndoEuropean Long Vowels in the Final Syllables of Germanic Polysyllables.” Transactions of the Philological Society 86, no. 2 (1988): 115-143.

Stockwell, Robert P. "Some Recent Theories of Old English Metrics." In Early English Metrics, edited by Christopher McCully and J. J. Anderson, 73-94. Cambridge: Cambridge University Press, 1996.

Suzuki, Seiichi. "In Defense of Resolution as a Metrical Principle in the Meter of Beowulf." English Studies 76, no. 1 (1995): 20-33.

— "Preference Conditions for Resolution in the Meter of Beowulf: Kaluza's Law Reconsidered.” Modern Philology 93, no. 3 (1996): 281-306.

The Metrical Organization of Beowulf: Prototype and Isomorphism. Trends in Linguistics: Studies and Monographs 95. Berlin: Mouton de Gruyter, 1996.

Terasawa, Jun. Old English Metre: An Introduction. Toronto: University of Toronto Press, 2011. 
Tolkien, J. R. R. Finn and Hengest: The Fragment and the Episode. Edited by Alan Bliss. Boston: Houghton Mifflin, 1982.

- Beowulf: A Translation and Commentary. Edited by Christopher Tolkien. London: HarperCollins, 2014.

Williams, R. A. The Finn Episode in Beowulf: An Essay in Interpretation. Cambridge: Cambridge University Press, 1924.

Yakovlev, Nicolay. "The Development of Alliterative Metre from Old to Middle English.” DPhil diss., University of Oxford, 2008. https://ora.ox.ac.uk/objects/uuid:02e46bb4-0abb-479d-9c5064be689e013e 